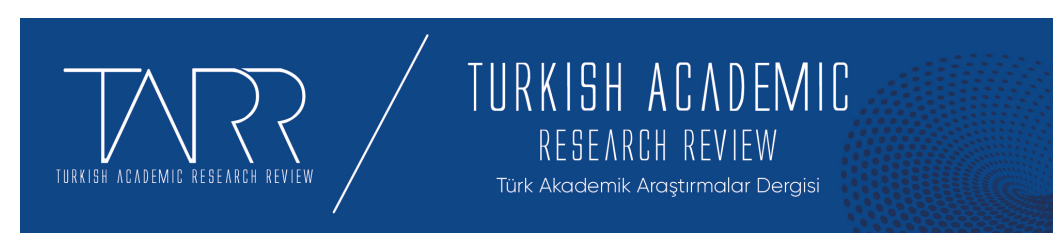

e-ISSN: 2602-2923 Yıl/Year: 2021 Cilt/Volume: 6 Sayı/Issue: 2

\title{
Midyat Telkâri Ustaları
}

Midyat Filigree Masters

\section{Gültekin AKENGİN - Meral BÜYÜKYAZICI - Tark DEMİR}

Prof. Dr., Ankara Hacı Bayram Veli Üniversitesi Sanat ve Tasarım Fakültesi, gultekinakengin@gmail.com, Orcid ID: 0000-0002-5399-2731,

Dr. Öğretim Üyesi, Ankara Hacı Bayram Veli Üniversitesi Sanat ve Tasarım Fakültesi, mbuyukyazı1@gmail.com, Orcid ID: 0000-0002-6760-7961,

Uzman, tdemir771@gmail.com, Orcid ID: 0000-0002-9516-4491

\begin{tabular}{r|l} 
Makale Bilgisi & Article Information \\
Makale Türü - Article Type & Araştırma Makalesi / Research Article \\
Geliş Tarihi - Date Received & 10 Mayıs / May 2021 \\
Kabul Tarihi - Date Accepted & 23 Haziran / June 2021 \\
Yayın Tarihi - Date Published & 25 Haziran / June 2021 \\
Yayın Sezonu & Nisan - Mayıs- Haziran \\
Pub Date Season & April - May - June
\end{tabular}

Atıf / Cite as: Gültekin, A.-Büyükyazıc1, M.-Demir, T. (2021). Midyat Telkâri Ustalar1/ Midyat Filigree Masters. Turkish Academic Research Review, 6 (2), 752 771. Retrieved from https://dergipark.org.tr/tr/pub/tarr/issue/62824/935572

Intihal / Plagiarism: Bu makale, en az iki hakem tarafından incelenmiş ve intihal içermediği teyit edilmiştir. / This article has been reviewed by at least two referees and confirmed to include no plagiarism. https://dergipark.org.tr/tr/pub/tarr

Copyright (C) Published by Mehmet ŞAHIN Since 2016- Akdeniz University, Faculty of Theology, Antalya, 07058 Turkey. All rights reserved.

Turkish Academic Research Review - Türk Akademik Araştırmalar Dergisi 


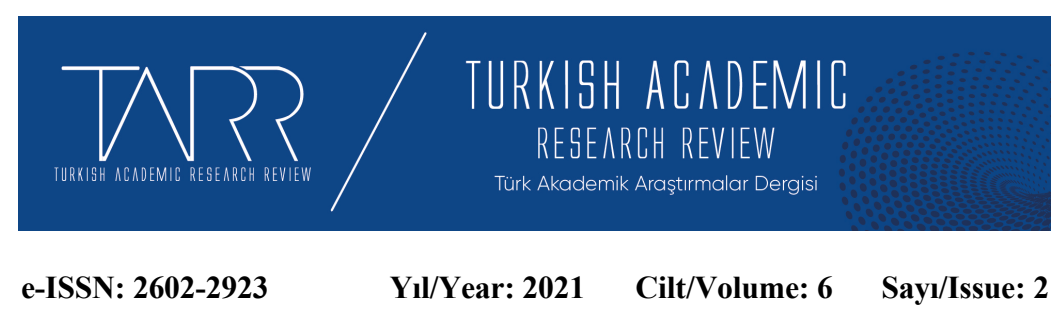

Midyat Telkâri Ustaları

Gültekin AKENGİN - Meral BÜYÜKYAZICI- Tarık DEMİR

$\ddot{O} \mathbf{z}$

2003 Yılında UNESCO tarafindan kabul edilen Somut Olmayan Kültürel Miras kavramı, 2006 yılında TBMM tarafından da kabul edilmiştir. Kültürel miras ürünü olan temsiller, anlatımlar, bilgiler, beceriler ve bunlara ilişkin araçlar, gereçler ve kültürel mekanlar Somut Olmayan Kültürel Miras kavramının çerçevesini oluşturmaktadır. Sözleşmenin en önemli konularından biri olan el sanatlarına beş alan dahil edilmiştir. Bunlar dokumacılık, nazar boncuğu, telkâri, bakırcılık ve halk mimarisidir. Anadolu'da 2500 yıllık bir geçmişe sahip telkârinin ülkemizde en önemli merkezlerinden olan Midyat, telkâride kullanılan malzemeleri, mesleği icra eden ustaları ve üretim süreçleriyle geleneksel özelliklerini korumaktadır. Türkiye'de Beypazarı, Trabzon ve Mardin'de işlendiği bilinen telkâri sanatıyla yüzyıllardır takı, ev aksesuarı, hediyelik eşya türünde eserler üretilmektedir. Midyat'la özdeşleşmiş olan telkâri, burada çoğunlukla Süryaniler tarafindan yapılan bir sanattır. 22 Mikrona varan tel inceliği ile son derece zarif ve göze hitap eden bir takı tekniği olan Midyat telkârisi kadim bir geçmişe sahiptir.

$\mathrm{Bu}$ çalışmada Yaşayan İnsan Hazineleri ölçütlerine uygun olduğu düşünülen üç telkâri ustasına ulaşılmıştır. Mevcut durumu araştırmak ve belirlemek amaciyla betimsel yöntem kullanılmıştır. Midyat telkârisini geleneksel üretim şekli ile günümüzde yaşatmaya çalışan ustalarla çalışma yapılmıştır. Ustalarla 2020 Aralık ayında atölye ortamında görüşme tekniği uygulanmıştır. Görüşme tekniği ile ustalara telkâri sanatı, bu sanatın geleneksel özellikleri, teknikleri, güncel durumu ve bu sanatın geleceğine dair sorular sorulmuştur. Bu çalışma telkâri sanatının geleneksel özelliklerini, güncel durumunu ve ustaların gelecek ile ilgili düşüncelerini ortaya koyması bakımından önemlidir.

Anahtar Kelimeler: Telkâri, Midyat Telkârisi, El Sanatları, Kültürel Miras, Telkâri Ustas1

\title{
Midyat Filigree Masters
}

\begin{abstract}
The concept of Intangible Cultural Heritage, which was accepted by UNESCO in 2003, has also been accepted by the Turkish Parliament in 2006. Performances, narrations, knowledge, skills and related tools, equipment and cultural venues, which are products of cultural heritage, form the framework of the Intangible Cultural Heritage. There are five areas included in handicrafts, which is one of the major aspects of the contract. These are weaving, amulet for evil eye, filigree, coppersmith and public architecture. The filigree of Midyat, which is one of the major centers of filigree art in Anatolia with a history of 2500 years, still preserves its traditional features with the materials used, craftsmen conducting this art and the production processes. For many centuries jewelries, home accessories, souvenirs are being manufactured with the filigree art seen in Beypazar1, Trabzon and Mardin in
\end{abstract}

Turkish Academic Research Review - Türk Akademik Araştırmalar Dergisi 
Turkey. Filigree, which is identified with Midyat are generally performed by Syriac Christians in this area. Midyat filigree, which has a very elegant and pleasant view with a wire thinness of 22 microns, has an ancient history.

In this study, we have accessed three filigree masters, who are believed to be decent for the criteria of Living Human Treasures. We have adopted descriptive method to research and identify the current situation, and we have accessed masters who are trying to continue the traditional manufacturing method for Midyat filigree. The masters have been interviewed in their workshops in December 2020. In the interviews the masters were asked questions about the filigree art, its traditional features, techniques, current situation and its future. This study is important since it shows the traditional features of the filigree art, its current status and the thoughts of the masters about its future.

Keywords: Filigree, Midyat filigree, Handicrafts, Cultural heritage, Filigree master.

\section{Structured Abstract}

Aziz Dilmeç, Melek Akyol, and Murat Aslan, who are among the most important living artisans of filigree art with a 3000 year past have been interviewed in a workshop. The masters who dedicate their lives to filigree art and earn their living by soldering filigree have stated that filigree production has become easier compared to 40-50 years ago due to technical developments. Especially, they have expressed that the stages of thinning the wire and welding with the torch are now a lot faster compared to the past. The masters have emphasized that training a filigree master is not an easy job and highlighted that it can take years. The three filigree masters, making a point of teaching their children the filigree art, have uttered their concerns about the continuation of this art. They have stated that especially the factory-made imitation products threaten the Midyat filigree and masters do not receive a recompense for their work.

The masters with ateliers in Midyat silversmiths bazaar have said that they design the filigree patterns themselves and are inspired by nature as well as traditional patterns. One of the masters, Aziz Dilmeç has stated that he has a sketchbook and draws the model in the book with actual sizes before making home accessories.

Melek Akyol and Aziz Dilmeç have worked in their own ateliers only. Murat Aslan works both in his atelier and the atelier of the Jewelry and Jewelry Design Program of Mardin Artuklu University Midyat Vocational Higher School. The masters, remarking that the best-selling product range has changed in time, have implied that the silver belt was in high demand in the past but today a set of three necklaces-bracelets and earrings has taken its place. Expressing that they are still working made-to-order, the masters have specified having customers all around Turkey. They have stated that pistol grips, silver trays, keychains, table name cards are popular products as gifts, and jewelry such as earrings-rings-necklaces-bracelets and anklets are very popular.

They have said that the Midyat filigree masters have decreased a lot in number, and a small number of Muslim masters have started to train besides Assyrian masters. The masters who believe that a control mechanism must be established through an official organization to prevent casting imitations of Midyat filigree, which requires effort and patience, have stated that a subsidy has been needed in this respect. 
The masters that have remarked having trained 250-300 people for the Midyat filigree art have stated that some of their apprentices have migrated abroad, some migrated to Istanbul, and there are not many people who continue this art except their children.

Among the masters, the Midyat filigree art has been performed by Aziz Dilmeç for 61 years, by Melek Akyol for 55 years, and by Murat Aslan for 35 years. All three masters fit the criteria of living human treasures with their specialties of having learned their arts through a master-apprentice relationship, their superiority in practicing their knowledge and skills, having rare knowledge in their field, dedicating their lives to filigree, and having taught their arts to the apprentices.

73 years old filigree master Aziz Dilmeç is a secondary school graduate. He also he is one of the oldest filigree masters of Midyat. He learned the art of filigree from Yusuf Aras, Musa Aras and Aslan Altınışık. He counted Simon Ünsal, Süleyman Tok, İbrahim Altunsu and Mirza Tezel as the most important masters of Midyat filigree art. Aziz Dilmeç, who has been dealing with this art for more than 60 years, stated that he taught filigree art to his children Aydın, Adnan, Kenan and Corç.

Melek Akyol, one of the most important living masters of Midyat filigree art. Akyol learned this profession from Sami Atuğ, Musa Aras and Süleyman Tok. He specified the Syriac filigree master Lahdo Ziftger, who lived 250-300 years ago, as the master of the Midyat filigree art, which he defines has a 1000-year history. Melek Akyol said that, "He was even producing mecidiye during the Ottoman period."

Murat Aslan, who was born in Midyat and graduated from secondary school. After working as an apprentice until 1990, he became a journeyman and worked as a pieceworker. Then he opened his own business in 1998. Murat Aslan, who has been practicing his profession for 35 years, stated that he started working in the workshop of his master Hanna Nayış, who was born in Midyat.

\section{Giriş}

El sanatları; insanların tabiatla mücadelesinde hayatta kalmak amaciyla ürettikleri aletlerle ortaya çıkmıştır. Daha sonra gelişerek değişimler gösteren el sanatları, ortaya çıktığı toplumun yaşam biçimini, dünyaya bakışını, geleneklerini ve sanat anlayışlarını yansıtan önemli kültürel boyutlar kazanmıştır.

El sanatı ürünler yerine göre günlük kullanım eşyasından süs eşyasına, çeyizlik eşyadan hediyelik eşyaya, pek çok ürünü içine alan dayanıklı tüketim malı olarak tanımlanabilir. Bu tür ürünler, el emeğine dayalı üretildiği için biri diğerinin aynı değildir ve her ürün tektir (Öztürk, 1998:7). Geleneksel bilgi ve beceriye dayanan el sanatları, döneminin en gelişmiş teknik imkanlarından faydalanmak yerine basit el araçları kullanılarak icra edilmiştir.

Geleneksel bilgi ve görgüyle üretilen el sanatı her ürün, el emeğine dayalı olarak üretildiğinden birbirinin aynısı değil tektir. Var olan bilgi, tasarım veya çizim 
değil, geleneksel bilgidir (Özdemir, 2010: 5). Geçmişten beri yaşayagelen, halk estetiğini ürünlere yansıtan, geleneksel yollarla çırak yetiştiren, el sanatlarıyla ilişkili meslekler, geleneksel meslekler kavramıla ifade edilmektedir (Yolcu, 2014:1-2). Geleneksel mesleklerde basit el aletleri ve kol gücü ön plana çıkmaktadır. Ancak modernleşmeyle beraber yaşanan teknolojik gelişmeler, seri üretim yapabilen fabrikalar, şehirleşmeyle birlikte geleneksel üretimlerin geri planda kalması, mesleklerini geleneksel usullerle sürdüren zanaatkarları olumsuz etkilemiştir.

Geleneksel meslekler atölye ortamında, usta-çırak ilişkisi içerisinde sürdürülmektedir. Mesleki tecrübeler bir okul ortamında değil, deneyimler yoluyla çırak ve kalfalara aktarılmaktadır. Geleneksel mesleklerin temel alanlarından biri olan el sanatları etrafında aynı zamanda bir kültür oluşmuş ve bu kültürel birikim nesilden nesile aktarılmıştır. Halk bilimi adı altında yapılan meslek folkloru araştırmalarında, disiplinler arası bakış açısıyla karşımıza çıkan en önemli kavramlardan biri el sanatlarıdır.

El sanatlarının genel özelliklerine bakıldığında aşağıdaki şu ortak hususlar dikkati çekmektedir:

1) El sanatları kişisel bilgi ve beceriye dayanır,

2) Bu bilgi ve beceri ustadan çırağa iletilir,

3) Bilgi iletimi ve üretimi süreklidir, böylece geleneksel özellik kazanır,

4) Kırsal üretimlerde hammadde yöreseldir,

5) Üretim kişiseldir, ya da küçük işletmelerde gerçekleştirilir,

6) Ürünler o topumun üretim ve yaşayış biçimiyle ekonomik düzeyinin aynısıdır (Sümerkan, 2008:9).

Teknik gelişmelerin hız kazandığı çağımızda geleneksel el sanatları ve bu sanatların etrafinda oluşan kültürel atmosferi muhafaza etmek, gelecek nesillere ulaştırmak oldukça zorlaşmıştır. 2003 Yılında UNESCO Genel Kurulu'nda Somut Olmayan Kültürel Miras kavramı kabul edilerek yürürlüğe girmiştir. 2006 Yılında ise Türkiye Büyük Millet Meclisi’nde çıkarılan bir kanunla Türkiye aynı sözleşmeye taraf olmuştur (Arığlu, 2006: 98). UNESCO Genel Kurulu'nda kabul edilen sözleşmenin 2. maddesinde geçen “...toplulukların, grupların ve kimi durumlarda bireylerin, kültürel miraslarının bir parçası olarak tanımladıkları uygulamalar, temsiller, anlatımlar, bilgiler, beceriler ve bunlara ilişkin araçlar, gereçler ve kültürel mekanlar..." ibaresi Somut Olmayan Kültürel Miras kavramının çerçevesini oluşturmuştur. 
Somut Olmayan Kültürel Miras sözleşmesinin alanlarından biri de el sanatları olarak belirlenmiştir. Sözleşme konusu el sanatları kavramına beş alan dahil edilmiştir: Dokumacılık, nazar boncuğu, telkâri, bakırcılık ve halk mimarisi.

$\mathrm{Bu}$ çalışmada geleneksel el sanatlarından kuyumculuk mesleğinin önemli bir tekniği olan telkâri ve telkârinin uygulandığı önemli merkezlerden biri olan Midyat telkârisi incelenmiştir. Çalışmada; Midyat telkârisinin yaşayan ustaları, geleneğin devamı ve sorunları üzerinde durulmuştur.

\section{Midyat Telkârisi}

Telkâri Farsça kâr (kari) ve tel kelimelerinden meydana gelmektedir. Latince'de bu kelimenin karşılığı filigran'dır. Arkeolojik kazılardan çıkan eserler, filigre tekniğinin, M.Ö. üçüncü binden itibaren Mezopotamya ve Misırda ve M.Ö. 2500'den itibaren de Anadolu'da kullanıldığını göstermektedir (Erginsoy, 1978:38). Midyat'ta ise gümüş dendiği zaman ilk akla gelen teknik telkâridir. Kelime manasından da anlaşılacağı gibi, telkâri, tel ile yapılan sanat manasına gelmektedir (Kuşoğlu, 2014:79). Bu teknikte ise tellere şekil verildikten sonra kaynakla birleştirilmekte ve ana iskeletin içi yine daha ince tellerle doldurulduktan sonra kaynak yapılmaktadır (Arlı, 1989:4).

Telkâri süsleme işçiliğinin M.Ö. 3000'den itibaren Mezopotamya ve Mısır'da, M.Ö. 2500 yılından sonra da Anadolu'da uygulandığı arkeolojik kazılarda meydana çıkan süslemeli eserlerden anlaşıldığından oldukça köklü bir geçmişe sahip olduğunu söylemek mümkündür. Türkiye'de Beypazarı, Trabzon ve Mardin illerinde işlendiği bilinen telkâri sanatıyla yüzyıllardır takı, ev aksesuarı, hediyelik eşya türünde eserler üretilmektedir. Yeter Fırat yüksek lisans tezinde, Midyat için “ Telkârinin Türkiye'de en gelişmiş kenti ve ilçesi” (Fırat, 2010: 43), ifadesini kullanmıştır. Midyat'la özdeşleşmiş olan telkâri, burada Süryaniler tarafindan yapılan bir sanattır. Bölgede yaşayan Süryaniler; telkârinin yanında taş işlemeciliği, çömlekçilik, bakırcılık, dokumacılık ve ayakkabıcılık gibi birçok el sanatı ile de uğraşmışlardır. “Osmanlı İmparatorluğu'nun 17. Yüzyıl sonları ile 20. Yüzyıl başlarındaki ekonomik durumu ve savaşlar nedeniyle kaybolmaya başlayan telkâri işçiliğinin en önemli merkezi Mardin ilinin ilçesi Midyat olmuştur. Midyat telkârisi oldukça zarif ve kıymetlidir ” (Büyükyazcı, 2008: 33). 1960’lı yıllara kadar Midyat ve çevresinde sadece Süryaniler telkâriyle uğraşmışlardır. 1960’lı yıllardan itibaren Midyat ve çevresinde ilk Müslüman telkâri ustaları yetişmeye başlamıştır.

Geleneksel sanatlar bir şehrin kimliğinin oluşmasında önemli bir role sahiptir. Taşın ve gümüşün işlendiği kadim bir şehir olan Midyat, tarihte birçok 
medeniyete ev sahipliği yapmıştır. Çok kültürlü yaşamın örnek hayatını temsil eden Midyat'ta Müslümanlar, Süryaniler ve Yezidiler birlikte yaşamaktadırlar. "Bölgede yaşayan Gayrimüslimler, bölgedeki sanat dalları ile ilgilenmişler ve çok iyi sanatkarlar yetiştirmişlerdir. Bu sanatların başında da gümüş işlemeciliği (telkâri) sanatı gelmektedir" (Kamiloğlu, 2009: 39). M. Zeki Kuşoğlu da, "Yurdumuzun en mühim telkâri merkezlerinin başında Mardin'in Midyat ilçesi gelir.” demiştir (Kuşoğlu, 2014:84).

Mardin'in Midyat ilçesi telkâri sanatının işlendiği en önemli merkez olarak turistik bir cazibe merkezi haline gelmiştir. Her y1l özellikle ilkbahar ve sonbahar aylarında yerli turistler başta olmak üzere yabancı turistleri de çekmeye başlamıştır. "Günümüzde takının yanı sıra turizm ile birlikte telkâri işçiliğiyle yapılan süs ve hediyelik eşya çeşitleri de fazlalaşmıştır" (Akyol, E. , 2017: 97). Geleneksel Midyat telkârisi, atölyeler ve gümüş satış mağazalarının bulunduğu Midyat gümüşçüler çarşısında işlenmektedir. "Çok eski tekniklerden biri olan telkâri gümüş işlemeciliğinin Anadolu'daki en güzel ve en eski örneklerinin Midyat yöresinde olduğu tespit edilmiştir.” (Sular, 1998: 73).

Telkâri işçiliği 22 mikrona varan tel inceliği ile son derece zarif ve göze hitap eden bir takı tekniğidir. Ancak teknolojinin hızla gelişmesi, üretmek yerine kolay ve hazır olan her şeyi büyük bir hızla tüketme isteği; telkâri sanatında da değişime neden olmaktadır. Yeni ustaların yetişmemesi ve sabır gerektiren bu mesleğe genç kuşağın ilgi göstermemesi bu konudaki en önemli sorunlardandır. Midyat'ta geleneksel usullerle telkâri üreten yaklaşık 20 atölye bulunmaktadır. Sayıları her geçen gün azalan Süryani telkâri ustalarının sayısı 40'1 geçmemektedir. Müslüman telkâri ustalarının sayısı ise daha azdır. Bu rakamlara gümüş ürünler satan Midyat gümüş̧̧ü esnafı dahil edilmemiştir.

Türkiye'de Somut Olmayan Kültürel Miras çalışmaları Kültür ve Turizm Bakanlığı uhdesinde yürütülmektedir. Bakanlığın bu kapsamda gerçekleştirdiği en önemli adımlardan biri Yaşayan İnsan Hazineleri Ulusal Envanteri çalışmasıdır. "Bu sistem somut olmayan kültürel mirası sürdüren usta insanların tanınması, sanatlarını iyi ortamlarda sürdürmelerinin sağlanması, ödüllendirilmesi, çırak yetiştirmeye özendirilmesi, örgün ve yaygın eğitim süreçlerine dahil edilerek kitlelerle buluşmalarına öncülük edilmesi gibi birçok amacı içermektedir" (Oğuz, 2008:6). Bu çalışmada ömrünü telkâri işçiliğine adayan üç Midyatlı Süryani telkâri ustasına yer verilmiştir. Her üç ustanın da; ustalıklarını en az 10 yıldır icra ediyor olmaları, sanatlarını usta-çırak ilişkisi ile öğrenmiş olmaları, bilgi ve becerilerini

Turkish Academic Research Review - Türk Akademik Araştırmalar Dergisi https://dergipark.org.tr/tr/pub/tarr 
uygulamadaki üstünlükleri, alanında ender bulunan bilgiye sahip olmaları, mesleklerine kendilerini adamışlıkları ve çırak yetiştirmedeki becerileri ile Yaşayan İnsan Hazineleri ölçütlerine uygun olduklarını ortaya çıkarmak, bu çalışmanın amacıdır.

Çalışmada, Yaşayan İnsan Hazineleri ölçütlerine uygun olduğu düşünülen üç telkâri ustasına ulaşılmıştır. Bu çalışmada mevcut durumu araştırmak ve belirlemek amacıyla betimsel yöntem kullanılmıştır. Midyat telkârisini geleneksel üretim şekli ile günümüzde yaşatmaya çalışan ustalarla çalışma yapılmıştır. Ustalarla 2020 Aralık ayında atölye ortamında görüşme tekniği uygulanmıştır. Görüşme tekniği ile ustalara telkâri sanatı, bu sanatın geleneksel özellikleri, teknikleri, güncel durumu ve bu sanatın geleceğine dair sorular sorulmuştur. $\mathrm{Bu}$ çalışma Telkâri sanatının geleneksel özelliklerini, güncel durumunu ve ustaların gelecek ile ilgili düşüncelerini ortaya koyması bakımından önemlidir.

\section{Midyat Tekâri Ustaları}

\subsection{Aziz Dilmeç}

73 Yaşındaki telkâri ustası Aziz Dilmeç, ortaokul mezunudur. Evli ve 5 çocuk sahibi olan Aziz Dilmeç, en yaşlı Midyat telkâri ustalarındandır. 1960 yılında bu sanatı öğrenen telkâri ustası, 15 yıl çıraklık yapmıştır. Telkâriyi Yusuf Aras, Musa Aras ve Aslan Altınışık’tan öğrenmiştir. Midyat telkâri sanatının en önemli ustaları olarak Simon Ünsal, Süleyman Tok, İbrahim Altunsu ve Mirza Tezel'i saymıştır. 60 yılı aşkındır bu sanatla uğraşan Aziz Dilmeç, telkâriyi çocukları Aydın, Adnan, Kenan ve Corç'a öğrettiğini, bazı çıraklarının ise yurt dışına gittiklerini belirtmiştir.

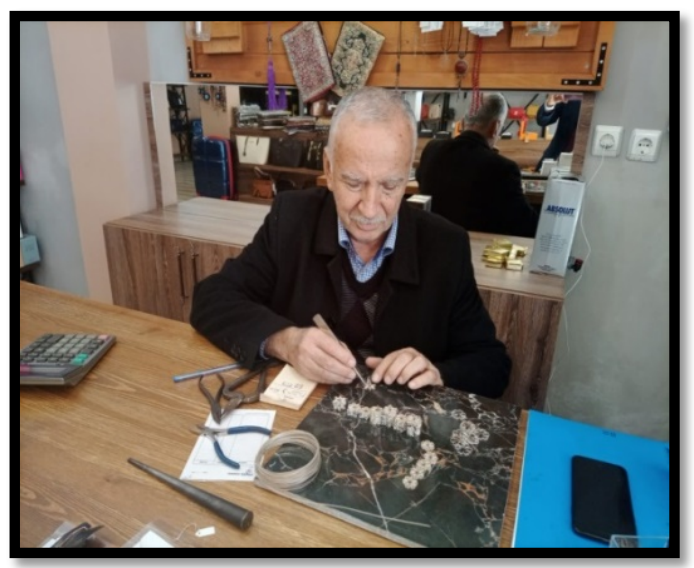

Fotoğraf 1: Aziz Dilmeç atölyesinde çalışırken (30.12.2020) 
Aziz Dilmeç yaptığı ürünlere eskiden çok talep olmadığını, Türkiye'de şehirleri dolaşıp toplu olarak ürünlerini sattıklarını, 30 sene önce Sivas'a, Erzurum'a, İstanbul'a götürdüklerini, telkâri ürünleri valizlere koyup gezdirdiklerini, gittikleri yerlerde mağazacılara sattıklarını, şimdi ise Midyat'ta gümüşçüler çarşısında sattıklarını belirtmiştir.

Eskiden kullandıkları malzemelerle günümüzde kullandıkları telkâri malzemeleri arasında büyük farklar olduğunu dile getiren Aziz Dilmeç, konuyla ilgili : "Eskiden bu kadar teknoloji yoktu. Mesela şu an tüp gazla çalışan şalimo yerine fitilli gaz lambasıyla yakardık. Her taraf toz duman olurdu. Eritme için de eskiden ocaklarımız vardı, çamurdan yaptığımız ocaklar, küçük küçük potalar, elle çevrilen hava veren çarklar vardı. Odun kömürüyle küçük bir potaya koyardık. Odun kömürüyle eritip çubuk haline getirirdik." şeklinde tespitlerini aktarmıştır.

Gümüşün ince tel haline getirilme süreciyle ilgili de şunları aktarmıştır: "Eskiden kol gücüyle çevrilen silindirler vardı. Elle çeviriyorduk. Daha sonra elektriklisi çıktı. Silindirden önce ise çekiçle, örsle yapardık bir çubuğu. Gümüş çubuğu ateşte ısıtıp yavaş yavaş inceltirdik. Ondan sonra büyük haddeler vardı. Bizim ustalarımız eskiden sırtına ip atarak büyük kerpetenle çubuğu çekerdi ta incelene kadar. O şekilde derece derece incelirdi, çok zordu. Şimdi zamanımızda o kollu makine çıktığında biz çok sevinmiştik. Birisi çeviriyordu kolu, diğeri çubuğu veriyordu ta inceltene kadar."

Gerçek bir esnaf ve zanaatkar nasıl olmalıdır sorusuna cevap veren Aziz Dilmeç, bir telkâri ustasının dikkat etmesi gereken hususları şöyle sıralamıştır: "Usta olması lazım, üretken olması lazım, tekniğini bilmesi lazım. Mesela bakıyoruz birisi bir parçayı yapıyor, kaynağını yaptığı zaman yarısını eritiyor, yarısını kaynakla boğuyor, sonra ben ustayım diyor. Önemli olan çıkardığı üründe işçiliği incelikleriyle göstermesi lazım. Çok hassas bir meslek.” Bir telkâri üründe kaynağın izlerinin kalmasını ya da kaynak yaparken ürünün gümüşünün eritilmesini büyük bir kusur olarak niteleyen Aziz Dilmeç, sanata kusursuz olduğu zaman önem verildiğini belirtmiştir.

1980’li yıllarda o zamanki ismiyle Turizm ve Tanıtma Bakanlığg'nın bir yarışmasına katıldığını ve ikinci olduğunu dile getiren Aziz Dilmeç, yarışmaya telkâri kolye ile katılmış ve eserinin çizimlerinin hala kendisinde bulunduğunu belirtmiştir.

Turkish Academic Research Review - Türk Akademik Araştırmalar Dergisi https://dergipark.org.tr/tr/pub/tarr 


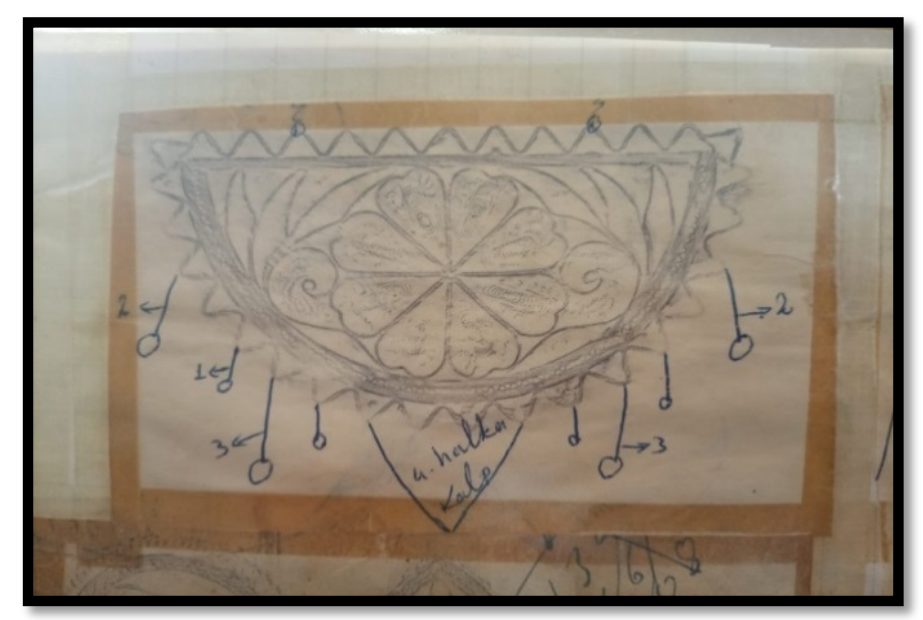

Fotoğraf 2: Aziz Dilmeç'in Yarışmaya katıldığı eserin çizimi (Aziz Dilmeç arşivi) (31.12.2020)

Bir telkâri ustasının en az 7-8 senede yetiştiğini belirtmiştir. Aziz Dilmeç, özellikle yapmaktan zevk aldığı ürünler olarak sigara tabakası, vazo ve şekerlik gibi ev aksesuarlarını sıralamıştır. "Benim için önemli olan parçanın kusursuzluğudur. Güzel ve mükemmel parça çıktığından çok mutlu oluyordum.” diyerek herkesten önce kendisinin beğenisinin önemli olduğunun altını çizmiştir. Ev aksesuarları için "büyük parçalar”, takılar için "küçük parçalar” tabirlerini kullanan Aziz Dilmeç, "Büyük parçaları yapmadan önce modelini çiziyordum. Benim büyük parçalar için yaptığım çizimler var. Fakat küçük parçalar için model çizmiyordum. Küçük parçalarda çiçek, papatya ağırlıklı desenler var. Büyük parçalara model çiziyordum.” diyerek ev aksesuarlarında, işe çizimle başladığını ifade etmiştir.

Midyat telkâri ustası Aziz Dilmeç, 950 ayar gümüşten el işiyle ürettiği orijinal vazosunun özelliklerini anlatırken, Midyat telkâri ustalarının kullandığg "ev" tabirinden bahsetmiştir. Vazonun üst kısmındaki kavisli çizimlere ev ismini verdiklerini, elinde bulunan vazoyu yaparken, ağız kısmında iki kanattan oluşan toplam 9 ev bulunduğunu belirtmiştir. Ağız kısmının altında ise "tırtır" dedikleri çerçeveler yer almakta ve bu çerçevenin içinde çiçek ve geometrik desenler bulunmaktadır. Aynı desenler vazonun alt kısmında da mevcuttur. Aziz Dilmeç, (ev, tırtır, gondol, büyük parçalar, küçük parçalar) tabirleriyle Midyat telkâri ustalarının sık kullandığı isimlendirmeleri telaffuz etmiştir. 


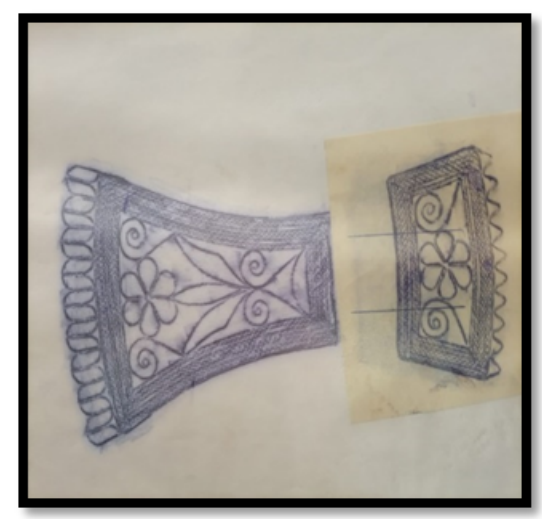

Fotoğraf 3:Aziz Dilmeç'e ait vazo çizimi bir vazo. (31.12 2020)

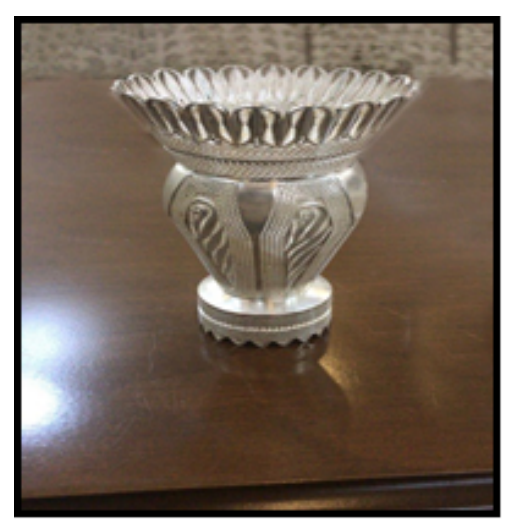

Fotoğraf 4: Aziz Dilmeç’e ait bitmiş

Sipariş üzerine yaptığı bir gümüş tepsinin zamanın Başbakanı Süleyman Demirel'e hediye edildiğini belirten Aziz Dilmeç, takı üretmekten de zevk aldığını ancak daha çok ev aksesuarları olarak Midyat telkârisiyle meyvelik (yörede gondol denilmekte), şekerlik, farklı büyüklüklerde çay-kahve-servis tepsileri, sigara kutusu, sigara ağızlığı, mücevher kutusu, vazo, ayna çerçevesi, çanta, resim çerçevesi, fincan kılıfı, şamdanlık, kaşık, eşya, masa isimliği, tabanca kabzaları ve kibritlik ürettiğini dile getirmiştir.

Midyat telkârisinin yaşayan en önemli ustalarından olan Aziz Dilmeç, kendisine ait 40-50 yıllık bir çizim defteri bulunduğunu, ürettiği eserlerin fotoğrafını çektiğini ve evinde kendi üretimi orijinal büyük parçalar bulunduğunu ifade etmiştir. Midyat telkâri sanatının geleceğiyle ilgili "Usta yetişmezse bu sanat ölür." diyen Aziz Dilmeç, emeğin karşılığını alamadığını, devlet desteğiyle atölyelerin açılması gerektiğini, gerçek ustalar eliyle yeniden çırak yetiştirilmesi gerektiğini belirtmiştir.

\subsection{Melek Akyol}

Midyat telkâri sanatının yaşayan en önemli ustalarından Melek Akyol, Midyat doğumludur ve 69 yaşındadır. Evli ve 8 çocuk babası olan Melek Akyol, ortaokul mezunudur. Telkâri sanatını 1966 yılında 14 yaşında öğrenmeye başlayan usta, mesleği Sami Atuğ, Musa Aras ve Süleyman Tok’tan öğrenmiştir.

"Başlangıç olarak darip dediğimiz zinciri başladım. Darip dediğim Halep'te yapılan zincir, pullu zincir ona darip diyoruz. Başlangıçta telkâriye nazaran daha kabadır teli. Mesela gerçek telkârinin inceliği 22 mikrondur, bu zincir 50

Turkish Academic Research Review - Türk Akademik Araştırmalar Dergisi 
mikron. Bakın 30 mikron fark var. Onda başladım, onu öğrendikten sonra yavaş yavaş inceye geçtim.”

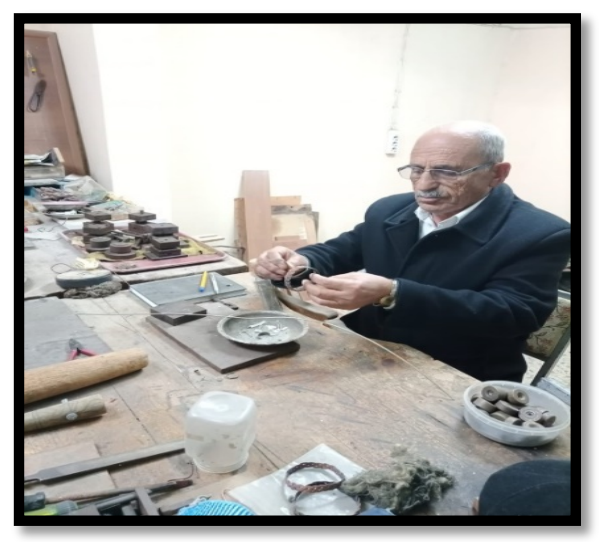

Fotoğraf 5: Melek Akyol atölyesinde çalışırken (31.12.2020)

1000 Y1llık bir geçmişi olduğunu belirttiği Midyat telkâri sanatının piri olarak, 250-300 yıl önce yaşamış Süryani telkâri ustası Lahdo Ziftger’i belirtmiştir. Melek Akyol, "Hatta Osmanlı döneminde kendisi mecidiye bile üretiyordu." demiştir. Telkâri mesleğini üç çocuğuna öğretmiş ve çocukları Sami, Ümit ve Uğur'un halen telkâri sanatıyla meşgul olduklarını ifade etmiştir.
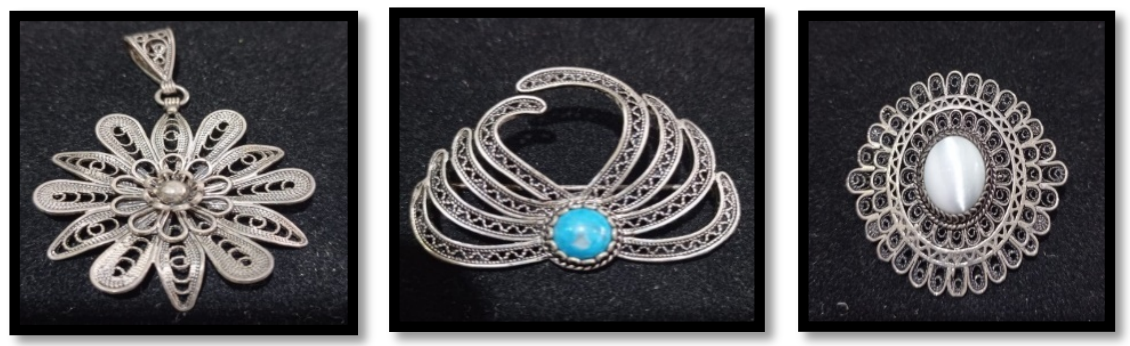

Fotoğraf 6-7-8: Melek Akyol'a ait takı örnekleri (31.12.2020)

Midyat gümüşçüler çarşısında kendi atölyesinde çocuklarıyla birlikte gümüş telkâri üreten Melek Akyol, kendi ürünü el işi geleneksel Midyat telkârisini satmaya devam etmektedir. Hem yerli turistlere satış yaptığını hem de sipariş üzerine çalıştıklarını belirten Melek Akyol, "Ülkemizin her yerinden müşterilerim var. Eskiden doğudan çok talep olurdu. Hakkari, Van, Yüksekova taraflarında eskiden bir gelin kemersiz, takımsız gelin gitmezdi. (Şimdi set diyoruz.) Tabi dökümler çıktığından beri el işi diye basit işler satılınca onlara artık sipariş vermiyorlar. El emeği göz nuru olduğu için çok kıymet veriyorlardı.” demiştir. 
Melek Akyol, eskiden gümüş kemere çok rağbet olduğunu, günümüzde ise kemerin ağır geldiğini, onun yerini üçlü setin (kolye-küpe-yüzük) aldığını belirtmiştir. Telkâride günümüzde kullanılan malzemelerle geçmişte kullanılan malzemelere yönelik "Eskiden makine yoktu, çekiçle dövüyorduk. Çok zahmetlerle çekiliyordu. Ondan sonra kollu makineler çıktı. Elektrik yoktu 60'l1 y1llarda. Makineyi kolla çekiyorduk. $\mathrm{O}$ vakitler diyelim ki 1 kilo gümüşü 2 günde kolla çekebiliyorduk. Şimdi ise yarım saatte 1 kiloyu çekeriz makinede. Teknoloji o kadar ilerledi." demiştir.

Zaman zaman yurt dışından sipariş aldığııı, Avusturalya'ya, Amerika'ya ve Avrupa ülkelerine telkâri ürünlerinin satıldığını belirten Melek Akyol, geçmişin esnaf ve zanaatkarıyla günümüzün arasında farklar olduğunu, eskiden dürüstlük ve saygıya daha çok önem verildiğini dile getirmiştir. Mesleğin geçmişteki ve günümüzdeki durumuyla ilgili şunları ifade etmiştir: "Bu döküm ürünler çıkmadan önce kuyumcuyum dediğimde bazı insanlar ceketlerini düğümlerdi, saygı gösterirlerdi. Fakat günümüzde taklitler ortaya çıkınca, döküm çıkınca kuyumcuyum dediğim zaman eski alakayı görmüyorum". Meslekte karşılaşılan en önemli sorun olarak, kuyumculuğu bilmeyenlerin gümüş ürünleri satmasını göstermektedir. "Gümüsş̧üyse gümüşün kalitesini bilecek. Altıncıysa altının ayarından anlayacak. Şimdi bazı kişiler kaplama yapıyor, üstü kağıt kadar gerçek altın, içi bakır, içi başka bir metal. Bunlar sahtekarlıktır, mesleği öldürüyorlar." diyen Melek Akyol "Şimdi döküme karşı değilim. Ben el işi 10 parça yapıncaya kadar döküm işi 200 parça çıkarılır. Döküme karşı değilim yalnız düşük ayar çalışmasınlar, ben ona karşııım. Bir de dökümü el işi diye satıyorlar. En büyük sıkıntı budur." diyerek fabrikasyon ürünlerin el işi şeklinde tanıtılmasına karşı olduğunu belirtmiştir. Mesleğin devamıla ilgili gerçek bir kontrol mekanizmasına duyulan ihtiyacı belirten Melek Akyol, özellikle Kuyumcular derneğinin önemli bir rol oynayabileceğine işaret etmiştir.

En çok papatya motifini kullandığını belirten Melek Akyol, motifleri doğadan ve ağaçlardan taklit ederek kendisinin çıkardığını söylemiştir. Küpe, yüzük ve kolyeden oluşan telkâri setin ve yaka iğnesinin (broş) çok satıldığını ifade eden Melek Akyol, ev aksesuarları olarak kullanılan gümüş tepsinin çok tutulduğunu belirtmiştir. Kahve ve çay bardaklarının konduğu gümüş tepsi için "Tamamen el işi gümüş. Bir kilo gümüş çıkıyor. Biz tepsiye gondol diyoruz. Bir de kayık şeklinde ve yuvarlak şekilde olmak üzere iki şekerlik modelimiz var." diyerek telkârinin takı dışında büyük parçalarda da kullanıldığını belirtmiştir. Midyat telkâri ustası Melek Akyol, kendisinde 1941'de yapılan bir ürün bulunduğunu belirterek, "Daha ben

Turkish Academic Research Review - Türk Akademik Araştırmalar Dergisi 
doğmadan, Musa Aras tarafindan 1941'de yapılmış bir vazo var. Parlatmıyorum bende duruyor, satmıyorum. Ustalarımdan hatıra.” demiştir.

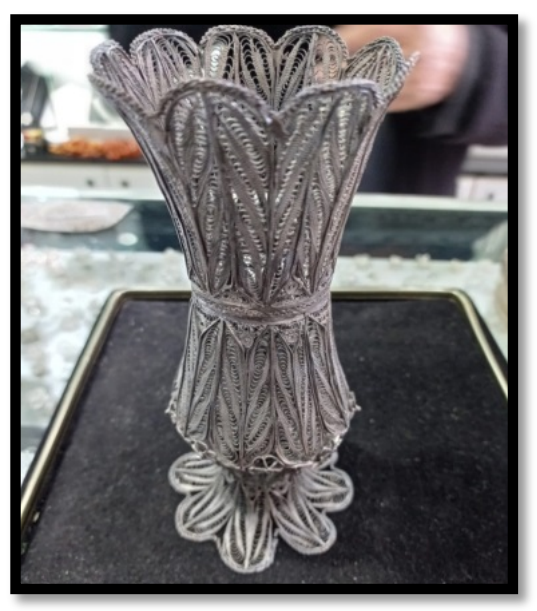

Fotoğraf 9: 1941 yılında telkâri ustası Musa Aras tarafından yapılan telkâri vazo $(31.12 .2020)$

Melek Akyol, telkâri sanatının Midyat'ta eski bir geçmişe sahip olduğunu ve telkâri işlemelerin günlük hayatta kullanılan bazı eşyalara da uygulandığını şu sözleriyle ifade etmiştir. "Bende bir de 150 ylllık telkâri işlemeli bir zurna var. Zurnaya özel işleme yaptım. Bende hatıra olarak duruyor. Onu satmıyorum.”

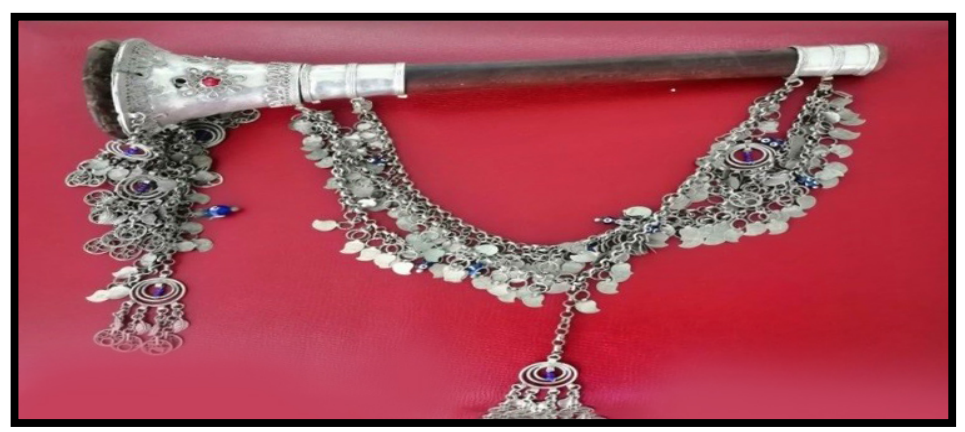

Fotoğraf 10: Telkâri işlemeli zurna (Melek Akyol arşivi) (31.12.2020)

\subsection{Murat Aslan}

Midyat doğumlu ve ortaokul mezunu olan Murat Aslan 46 yaşındadır. Evli ve dört çocuk babası olan usta, 1985 yılında 11 yaşında iken telkâri ustalarının yanında çırak olarak mesleğe başlamıştır. 1990 Yılına kadar çırak olarak çalıştıktan sonra kalfalığa geçmiş, parça başı olarak çalışmış, 1998'de kendi işyerini açmıştır. 


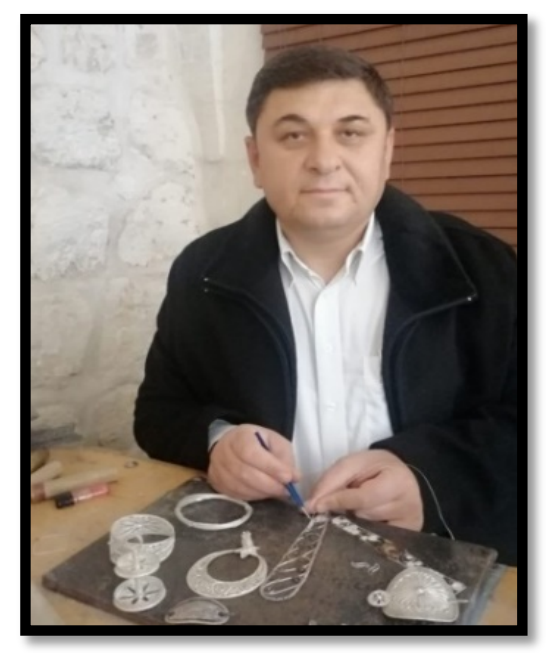

Fotoğraf 11: Murat Aslan atölyede çalışırken (30.12.2020)

Mesleğini 35 yıldır icra eden Murat Aslan, ustası Midyat doğumlu Hanna Nayış'ın atölyesinde işe başladığını belirtmiştir. Diğer ustası da halen Almanya'da bulunan Konstantin Akgün'dür. Bu mesleği öğrenmeye başlayan çırakların çoğu gibi mesleğe, telkâride iç dolgu olarak kullanılan "Teker" diye tabir edilen 22-24 mikron inceliğindeki teli çevirerek, iç dolgu hazırlayarak başlamıştır.

Devlet Personel Başkanlı̆̆ı'nın 2016 yılında meslekler listesinde "telkâri ustası" adıyla yeni bir meslek ihdas etmesinin ardından Mardin Artuklu Üniversitesi Midyat MYO Kuyumculuk ve Takı Tasarımı programında, telkâri ustası olarak göreve başlamıştır. Yaklaşık 5 yıldır bu görevi sürdürmekte olan Murat Aslan "telkâri ustası" ünvanlı ilk devlet memurudur.

Yılda ortalama 20 öğrenciye telkâri sanatını atölye ortamında öğrettiğini belirten Murat Aslan, "5 yıllık süreç içerisinde kendi atölyesini açanlar oldu. Gümüşçü dükkanlarında çalışanlar oldu. Şu an üniversitemize bağlı Midyat Telkâri Tasarım ve Uygulama Merkezi’nde 7 mezunumuz ekmeğini kazanıyor. Pandemiden önce bu sayı 15'e kadar yükselmişti." demiştir.

Murat Aslan bu mesleğin piri konusunda "Son zamanlarda bildiğim 1 yıl önce vefat eden Süleyman Tok, oğlu Yakup Tok ve bir de 150 yıl önce yaşamış Sami Çeni” bilgisini vermiştir. Mesleğin tarihi ile ilgili bilgisi konusunda “Araştırdı̆̆ım kadarıyla 3000 yıllık bir sanattır, ilk 2000 yıl bakırla, son bin yıldır gümüşle işlenmiştir. Bakırla yapıldığı dönemlerde; Diyarbakır'da bakır madeni bulunduğu için hammadde buradan temin edilirmiş. Bakır ile daha çok kemer, bileklik ve küpe işlenmiştir." şeklinde bilgi vermiştir.

Telkâri mesleğinde geçmişte; Midyat'ta 40 atölyenin açık olduğu günlerde yaklaşık 60-70 ustanın, 400 kadar kalfanın ve 200-300 kadar da çırağın

Turkish Academic Research Review - Türk Akademik Araştırmalar Dergisi https://dergipark.org.tr/tr/pub/tarr 
bulunduğunu ve bu atölyelerde toplamda 700'ü aşkın kişinin çalıştığını, 25-30 yıl öncesine kadar durumun bu şekilde devam ettiğini belirtmiştir.

Murat Aslan, telkâri geleneğiyle geçmişte bardak altı, fincan, mektup zarfi yapıldığını, günümüzde ise alternatiflerin çoğalarak tepsi, bardak kılıfi, çanta, vazolar ve vitrin aksesuarlarının telkâri tekniği ile uygulandığını belirtmiştir.

Geçmişte telkâride kullanılan tekniklerin uygulanmasına yönelik tespitlerini aktarırken, kaynak işleminde kullanılan şalimonun, eskiden gaz yağı ile doldurulup üflenerek yakıldığını belirtmiştir. Sabahtan akşama kadar ağızlarıyla üfleyerek Şalimo başlığındaki gaz yakılmaya çalışılmış ve ciddi bir emek harcanmıştır. 50-60 Yıl öncesine kadar eritme işleminin bugünkü gibi elektrikli ve tüplü ocaklar yerine kömürle, el yordamıyla yakıldığını ifade etmiştir: "Kömür körükle üflenir, pervane ile harlanırdı." Gümüş telin inceltilmesi aşaması ise Murat Aslan tarafından şu sözlerle anlatılmıştır: "Kalın teli inceltmek için eskiden iki usta sırtlarına deri yelek giyerlerdi, bunun nedeni tellerden sırtların etkilenmemesi içindir. İki usta pense uçlarıyla çekerek teli inceltirlerdi. Kas gücüyle (sırt gücüyle) çektikleri teller telkâride kullanılırdı. Şimdi ise makineler kullanılmaktadır."

Günümüzde telkâri ürünleri satmakta zorlandıklarını ifade eden Murat Aslan, bir atölyede eskiden 10 kişinin çalıştı̆ı̆ını, geçimini temin ettiğini, şimdi ise bir atölyede çalışan kişi sayısının 4-5'e düştüğünü belirterek döküm ürünlerin artmasıyla beraber rekabette zorlandıklarını şu sözlerle dile getirmiştir: " Fiyat olarak bu telkâriye yansıyor. Telkâri hak ettiği değeri bulmadığı için eskisi kadar üretilmiyor. Telkâri döküm ürünler karşısında ayakta durmakta zorlanıyor. Tanıtımın olmayışı da etkiliyor. Ya da insanlar yani bazı esnaflar telkâriyi yanlış tanıttıklarından, telkâri hak ettiği değeri bulamıyor. Döküm ürünlerini telkâri diye pazarlayanlar var."
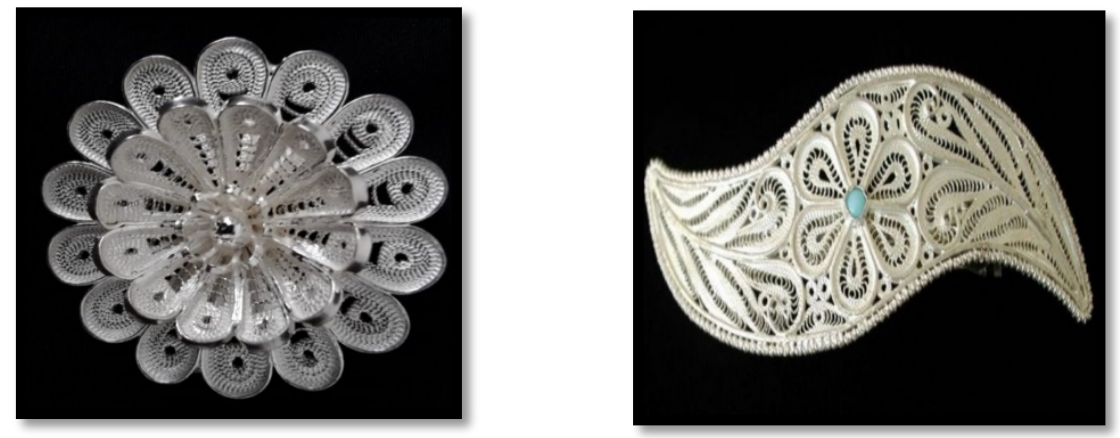

Fotoğraf 12-13: Murat Aslan'a ait takı örnekleri (30.12.2020) 
Esnaf ve zanaatkar kimdir sorusuna telkâri ustası Murat Aslan, "Bence esnaf ve zanaatkar ahlakıyla, dürüstlüğüyle işi a'dan z’ye kadar, eritmeden parlatmaya kadar yapabilen kişidir. Sadece bu işi (telkâriyi) alıp satan kişi değildir. Ürünü alıp satan kişi sadece tüccardır bence. Telkâriyi satan kişi üretici değildir, esnaf değildir.” şeklinde cevap vermiştir. Geçmişin telkâri esnaf ve zanaatkarıyla günümüzdekiler arasında arasında mukayese yapan Murat Aslan eskilerle günümüz esnafı arasındaki farkı eski telkâri ustalarının söylediği şu sözle belirtmiştir: "Biz sanat satıyoruz, gümüş satmıyoruz."

Telkâri ustası Murat Aslan mesleğiyle ilgili karşılaştı̆ı en önemli sorun olarak “ En büyük sıkıntımız Midyat telkârisi adı altında farklı bir döküm ürünün satılmasıdır. Çünkü yerli turistler geldiğinde, özellikle biz Midyat gümüşü istiyoruz dediklerinde esnaflarımızın bazıları maalesef döküm veya Çin'den aldıkları ürünleri Midyat telkârisi olarak satıyorlar. Bu gerçekten büyük bir eksiklik.” demiştir. Mesleğinin gelecekteki durumuyla ilgili olarak ise Murat Aslan, şu anda atölyesinde ailesinden 8 kişinin çalıştığını, kendi ölçeğinde aile olarak bu sanatı devam ettireceklerini ifade etmiştir.

\section{Sonuç}

3000 bin yıllık geçmişe sahip telkâri sanatının yaşayan en önemli zanaatkarlarından olan Aziz Dilmeç, Melek Akyol ve Murat Aslan'la atölye ortamında görüşme yapılmıştır. Ömürlerini telkâri sanatına adayan, hayatlarını telkâri işleyerek kazanan ustalar, teknik gelişmeler sebebiyle telkâri üretiminin 4050 yıl öncesine nazaran daha kolaylaştığını dile getirmişlerdir. Özellikle telin inceltilmesi ve şalimoyla kaynak yapılması aşamalarının eskiye göre çok daha hızlı gerçekleştiğini belirtmişlerdir. Bir telkâri ustasının yetişmesinin kolay bir iş olmadığına vurgu yapan ustalar bunun yılları alabileceğine dikkati çekmişlerdir. Kendi çocuklarına telkâri sanatını öğretmeyi ihmal etmeyen üç telkâri ustası, bu sanatın devamıyla ilgili endişelerini dile getirmişlerdir. Özellikle fabrikasyon taklit ürünlerin Midyat telkârisi için bir tehlike olduğunu, ustaların emeğinin karşıllğıını alamadığını belirtmişlerdir.

Midyat gümüş̧̧üler çarşısında atölyeleri bulunan ustalar, telkâri motiflerini kendilerinin tasarladığını, geleneksel motiflerin yanında tabiattandan da ilham aldıklarını belirtmişlerdir. Ustalardan Aziz Dilmeç kendisine ait çizim defteri 
bulunduğunu, ev aksesuarlarını yapmadan önce modeli defterine gerçek ölçüleriyle çizdiğini ifade etmiştir.

Melek Akyol ve Aziz Dilmeç sadece kendi atölyelerinde çalışmışlardır. Murat Aslan ise hem kendi atölyesinde hem de Mardin Artuklu Üniversites Midyat Meslek Yüksekokulu Kuyumculuk ve Takı Tasarımı Programı atölyesinde çalışmaktadır. En çok satılan ürün yelpazesinin zamanla değiştiğini belirten ustalar, eskiden gümüş kemere çok rağbet olduğunu, günümüzde ise bunun yerini kolyebileklik ve küpeden oluşan üçlü setin aldığını belirtmişlerdir. Hala sipariş üzerine çalıştıklarını ifade eden ustalar, Türkiye'nin her yerinden müşterileri olduğunu belirtmişlerdir. Silah kabzaları, gümüş tepsiler, anahtarlık, masa isimliği gibi ürünlerin hediye amaçlı talep edildiğini, küpe-yüzük-kolye-bileklik ve halhal türü takıların çok rağbet gördüğünü ifade etmişlerdir.

Midyat telkâri ustalarının sayılarının çok azaldı̆̆ını, Süryani ustaların yanında az sayıda Müslüman ustaların da yetişmeye başladığını dile getirmişlerdir. Emek ve sabır isteyen Midyat telkârisinin döküm taklitlerinin önüne geçmek için resmi bir kuruluş marifetiyle kontrol mekanizmasının kurulması gereğine inanan ustalar, bu konuda devlet desteğine ihityaç duyulduğunu belirtmişlerdir.

Midyat telkâri sanatını 250-300 kişiye öğrettiklerini belirten ustalar, çıraklarının bir kısmının yurt dışına, bir kısmının İstanbul'a göç ettiğini, çocukları dışında bu sanatı devam ettiren pek kimse kalmadığını ifade etmişlerdir.

Ustalardan Aziz Dilmeç 61 yll, Melek Akyol 55 yıl ve Murat Aslan 35 yıl Midyat telkâri sanatını icra etmişlerdir. Sanatlarını usta-çırak ilişkisi ile öğrenmiş olmaları, bilgi ve becerilerini uygulamadaki üstünlükleri, alanında ender bulunan bilgiye sahip olmaları, ömürlerini telkâriye adamış olmaları ve sanatlarını çıraklara öğretmiş olma özelliğiyle her üç usta da, yaşayan insan hazineleri ölçütlerine uymaktadır. 


\section{Kaynakça}

Arıoğlu, İ.E, (2006). Somut Olmayan Kültürel Mirasın Korunması Sözleşmesi TBMM'de Kabul Edildi”, Milli Folklor Uluslarası, Kültür Araştırmaları Dergisi, (69), 186-187.

Akyol, E. (2017). Kültürün Korunması ve Aktarımı Bağlamında Beypazarı'nda Telkâri Sanatı ile Ustaları Üzerine Bir Derleme ve Değerlendirme, Sosyal ve Beşeri Bilimler Araştırmaları Dergisi, (40), 90-109.

Arlı, M., (1989). Beypazarı'nda Telkâri Üzerinde Bir Araştırma, Ankara: Ankara Üniversitesi Ziraat Fakültesi Yayınları.

Büyükyazıc1, M. E., (2008), Trabzon Illinde Altın ve Gümüş Işslemeciliği, Yayınlanmamıș Doktora Tezi, Ankara Üniversitesi, Fen Bilimleri Enstitüsü, Ankara.

Bingöl, F.R., (1999). Antik Takılar, T.C. Kültür Bakanlığı Anıtlar Müzeler Genel Müdürlüğü, Ankara

Erginsoy, Ü. (1978). İslam Maden Sanatının Gelişmesi, Kültür Bakanlığı Yayınları, İstanbul.

Fırat, Y. (2010), Mardin İli Gümüşs Telkari Kadın Takıları, Yayınlanmamış Yüksek Lisans Tezi, Gazi Üniversitesi, Eğitim Bilimleri Enstitüsü, Ankara.

Kamiloğlu, İ. E., (2009). Mardin İli Gümüş Işslemeciliği ve Yörede Yapılan Ürünlerin Bazı Özellikleri, Yayınlanmamış Doktora Tezi, Ankara Üniversitesi Fen Bilimleri Enstitüsü, Ankara.

Kuşoğlu, M.Z. (2014). Türk Sanatında Gümüş, İBB Yayınları, İstanbul.

Öztürk, İ. (1998). Geleneksel Türk El Sanatlarına Giriş, Ürün Yayınları, Ankara.

Özdemir, M. F., (2010). Beypazarı Telkari İşlemeciliği ve Takı Örneklerinin Incelenmesi, Yayınlanmamış Yüksek Lisans Tezi, Gazi Üniversitesi, Fen Bilimleri Enstitüsü, Ankara.

Sular, G., (1998). Mardin İli Midyat İlçesi Telkari Gümüş İşçiliği Üzerine Bir Araştırma, Yayınlanmamış Yüksek Lisans Tezi, Gazi Üniversitesi, Fen Bilimleri Enstitüsü, Ankara.

Oğuz, M.Ö. (2008). Unesco ve Geleneğin Ustaları, Milli Folklor Uluslarası, Kültür Araştırmaları Dergisi, (77), 5-10.

Turkish Academic Research Review - Türk Akademik Araştırmalar Dergisi https://dergipark.org.tr/tr/pub/tarr 
770 Midyat Telkâri Ustaları

Sümerkan, M.R, (2008). Trabzon Yöresi Geleneksel El Sanatlarl, Serander Yayinevi, Trabzon.

Yolcu, M.A. (2014). Nevşehir Yöresinde Yaşayan Geleneksel Meslekler, Ankara: Nevşehir Hacı Bektaş Veli Üniversitesi Yayınları. 


\section{Kaynak Kişler:}

1.Kaynak Kişi: Aziz Dilmeç

Doğum Tarihi: 1948

Doğum Yeri: Midyat

Eğitim Durumu: Ortaokul

2.Kaynak Kişi: Melek Akyol

Doğum Tarihi: 1958

Doğum Yeri: Midyat

Eğitim Durumu: Ortaokul

3.Kaynak Kişi: Murat Aslan

Doğum Tarihi: 1974

Doğum Yeri: Midyat

Eğitim Durumu: Ortaokul

Turkish Academic Research Review - Türk Akademik Araştırmalar Dergisi https://dergipark.org.tr/tr/pub/tarr 